\title{
Oględziny zwłok zakopanych i oględziny miejsca ujawnienia zwłok w przypadku podejrzenia przestępnego spowodowania śmierci — propozycja organizacji czynności procesowych.
Studium przypadku
}

Michal WePsięć

ORCID: 0000-0002-4309-9990

Lekarz medycyny sądowej, biegły przy Sądzie Okręgowym we Wrocławiu

\section{MACIEJ TRZCIŃSKI}

ORCID: 0000-0002-6308-3187

Katedra Kryminalistyki

Wydział Prawa, Administracji i Ekonomii Uniwersytetu Wrocławskiego

\section{Wprowadzenie}

Oględziny jako czynność procesową reguluje treść art. 207 i 209 k.p.k. ${ }^{1}$ Art. 207 warunkuje możliwość dokonania oględzin miejsca, osoby i rzeczy, natomiast art. 209 k.p.k. odnosi się bezpośrednio do oględzin

1 Ustawa z dnia 6 czerwca 1997 roku Kodeks postępowania karnego, Dz.U 2020 poz. 30 . 
zwłok $^{2}$. W przypadku podejrzenia przestępnego spowodowania śmierci człowieka oględziny zwłok i miejsca, a często rzeczy i osób, ze względów oczywistych są $\mathrm{z}$ sobą powiązane i często prowadzone są w tym samym czasie lub tuż po sobie. Jest to uzależnione od charakterystyki miejsca ujawnienia zwłok, wstępnie ustalonych okoliczności zdarzenia, możliwości technicznych oraz przyjętej przez funkcjonariusza prowadzącego czynności strategii działań (planu oględzin).

Zgodnie z treścią art. 209 k.p.k. ${ }^{3} \mathrm{w}$ oględzinach zwłok powinien brać udział biegły lekarz, najlepiej specjalista medycyny sądowej, jednak ze względu na małą liczbę specjalistów medycyny sądowej w Polsce, a także niskie stawki wynagradzania biegłych, niejednokrotnie funkcjonariusz prowadzący czynności nie ma możliwości zapewnienia udziału biegłego w prowadzonych czynnościach, co zdaniem autorów może mieć i ma negatywny wpływ na wyniki przeprowadzanych oględzin ${ }^{4}$.

Jeżeli chodzi o praktyczną organizację oględzin zwłok od strony technicznej, to problematyce tej zdaniem autorów nie poświęcono dotąd należytej uwagi ani w piśmiennictwie, ani w obowiązujących aktach prawnych. Zazwyczaj dość krótkie i zdawkowe omówienie praktycznej

2 Szerzej m.in.: W. Grzywno-Dąbrowski, Badanie zwłok i miejsca, gdzie byty znalezione, Warszawa 1959; M. Całkiewicz, Oględziny zwłok i miejsca ich znalezienia, Warszawa 2010.

3 „Art. 209 § 1. Jeżeli zachodzi podejrzenie przestępnego spowodowania śmierci, przeprowadza się oględziny i otwarcie zwłok. § 2. Oględzin zwłok dokonuje prokurator, a w postępowaniu sądowym sąd, $\mathrm{z}$ udziałem biegłego lekarza, w miarę możności z zakresu medycyny sądowej. W wypadkach niecierpiących zwłoki oględzin dokonuje Policja z obowiązkiem niezwłocznego powiadomienia prokuratora. § 3. Oględzin zwłok dokonuje się na miejscu ich znalezienia. Do czasu przybycia biegłego oraz prokuratora lub sądu przemieszczać lub poruszać zwłoki można tylko w razie konieczności. § 4. Otwarcia zwłok dokonuje biegły lekarz, w miarę możności z zakresu medycyny sądowej, w obecności prokuratora albo sądu. W postępowaniu przed sądem art. 396 $\S 1$ i 4 stosuje się odpowiednio. § 5. Do obecności przy oględzinach i otwarciu zwłok można, w razie potrzeby, oprócz biegłego, wezwać lekarza, który ostatnio udzielił pomocy zmarłemu. $\mathrm{Z}$ oględzin i otwarcia zwłok biegły sporządza opinię z zachowaniem wymagań art. $200 \S 2$ ".

${ }^{4}$ Krytycznie na ten temat m.in. w rozprawie doktorskiej A. Surwiło, Oględziny zwłok i miejsca ich znalezienia jako kompleksowa czynność postępowania przygotowawczego, Warszawa 2019 (maszynopis w archiwum Wydziału Prawa i Administracji Uniwersytetu Warszawskiego). 
organizacji i przebiegu oględzin zwłok można znaleźć w większości polskich podręczników z zakresu medycyny sądowej i kryminalistyki, brakuje jednak swego rodzaju wytycznych opartych na najlepszych praktykach, które opracowaliby doświadczeni specjaliści ${ }^{5}$.

Formalnie przebieg oględzin zwłok i miejsca ich ujawnienia regulują częściowo ustawa z dnia 6 kwietnia 1990 roku o Policji (Dz.U. $1990 \mathrm{Nr} 30$, poz. 179, z późn. zm.) oraz Wytyczne nr 3 Komendanta Głównego Policji z dnia 30 sierpnia 2017 roku w sprawie wykonywania niektórych czynności dochodzeniowo-śledczych przez policjan-

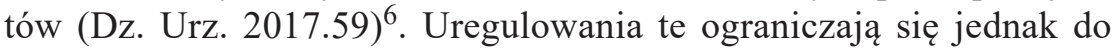
sformułowań ogólnych ${ }^{7}$, sporo uwagi poświęcając sporządzaniu dokumentacji, w tym również dokumentowaniu oględzin zwłok ${ }^{8}$ oraz zabezpieczaniu materiału dowodowego. Próżno jednak szukać w nich wskazówek dotyczących tego, jak mają wyglądać oględziny zwłok in situ, czyli w miejscu ich znalezienia.

Należy zwrócić uwagę, że przebieg oględzin zwłok oraz miejsca ich ujawnienia może mieć różny charakter, co związane jest m.in. z okolicznościami śmierci oraz miejscem prowadzenia czynności procesowych. Dla autorów jest sprawą oczywistą, iż w zależności od kontekstu, w jakim zwłoki zostały ujawnione, oraz skali trudności, jakich

5 Przykłady takich „manuali” (Best practice manual) w odniesieniu do różnych ekspertyz sądowych znaleźć można m.in. na oficjalnej stronie European Network of Forensic Sciences Institute — zob. http://enfsi.eu/documents/best-practice-manuals/ (dostęp: 2.03.2020).

6 Przede wszystkim przepisy z rozdziału 8 („Oględziny miejsca, osoby i rzeczy”).

7 Np. § 42.1. Celem oględzin jest ujawnienie i zabezpieczenie śladów przestępstwa lub ich nośników znajdujących się na miejscu zdarzenia, osobie lub rzeczy mogących mieć związek z przestępstwem, które mogą służyć jako źródła dowodowe w toku postępowania. 2. Oględziny miejsca zdarzenia polegają na dokonaniu czynności taktycznych i technicznokryminalistycznych zmierzających do poznania przebiegu zdarzenia, przeprowadzanych w sposób planowy, z uwzględnieniem właściwości obszaru (przestrzeni zamkniętej lub otwartej) oraz klasyfikacji różnych grup śladów przestępstwa lub ich nośników albo rzeczy, ich położenia, właściwości, stanu i cech indywidualnych.

8 § 45.2. W przypadku oględzin miejsca znalezienia zwłok ludzkich nie oznacza się zwłok numerem, a jedynie opisuje się w protokole ich umiejscowienie. Jeżeli znaleziono więcej niż jedne zwłoki ludzkie lub gdy w wyniku zdarzenia zwłoki zostały rozkawałkowane, oznacza się zwłoki lub ich części kolejnymi literami alfabetu łacińskiego. 
nastręcza przeprowadzenie oględzin, w celu zapewnienia odpowiedniej jakości oględzin kierujący oględzinami może lub wręcz powinien sięgnąć po pomoc biegłego lub specjalisty, na co zezwala art. $193 \S 1$ k.p.k. (biegły) oraz art. $205 \S 1$ k.p.k. (specjalista). Autorzy koncentrują swoją uwagę na sprawach dość powszechnych i relatywnie często występujących, które dotyczą ujawnienia pojedynczych, ukrytych, najczęściej zakopanych zwłok. Odrębnym problemem jest prowadzenie oględzin w miejscach katastrof masowych przy dużej liczbie ofiar. Oględzinami tego typu zajmują się interdyscyplinarne zespoły DVI (Disaster Victim Identification Team) ${ }^{9}$, a sprawy tego typu prowadzone są w odrębnym trybie ${ }^{10}$.

\section{Studium przypadku}

Do specyficznych okoliczności należy zaliczyć ujawnienie zwłok zakopanych. Zdarzenia tego typu mogą mieć charakter kryminalny i dotyczyć spraw, w których zabójca ukrywa zwłoki ${ }^{11}$, nie można jednak wykluczyć, że odkryte szczątki ludzkie można będzie powiązać z funkcjonowaniem dawnego cmentarza lub pojedynczej mogiły wojennej. Warto zatem już na wstępie przeprowadzić krótkie rozpoznanie historyczne terenu, na którym ujawnione zostały szczątki. Dość często zdarza się bowiem, iż organy procesowe podejmujące po zawiadomieniu czynności w miejscu ujawnienia zwłok (na ogół w oparciu o art. 155 k.k.)

${ }^{9}$ W czerwcu 2019 roku zespół taki utworzony został również w Polsce — zob. http://clkp.policja.pl/clk/aktualnosci/175202,Pierwsze-posiedzenie-polskiego-ZespoluDVI.html (dostęp: 2.03.2020).

10 Który określają: Procedury postępowania Policji podczas organizowania i przeprowadzania oględzin miejsca przestępstwa, stanowiące załącznik do pisma Komendanta Głównego Policji Ad-1078/2001 z dnia 7 sierpnia 2001 roku, oraz Metodyka prowadzenia oględzin miejsc przestępstw o charakterze terrorystycznym $i$ katastrof oraz identyfikacji ciał ofiar, stanowiąca załącznik do pisma Zastępcy Komendanta Głównego Policji Aom-1369/2012 z dnia 24 października 2012 roku.

11 Według przeprowadzonych ostatnio badań zakopywanie zwłok ofiary jest wciąż najczęściej spotykaną formą ich ukrywania przez sprawcę zabójstwa — por. A. Gawliński, Jak pozbyć się zwłok. Specyfika działania sprawców zabójstw i ich postępowanie ze zwłokami, Olsztynek 2018, s. 111. 
nie sprawdzają podstawowych informacji, z których wynikać może, iż np. miejsce to można wiązać z polem bitewnym lub nieistniejącym już cmentarzem itp.

Autorzy w toku swojej praktyki zawodowej nie natrafili na gruncie prawa krajowego na żadne formalne uregulowania dotyczące określenia sposobu oględzin zwłok zakopanych. Również jeśli idzie o fachową literaturę krajową, brakuje wskazówek lub praktycznych zaleceń, w jaki sposób taka czynność miałaby przebiegać. Prawdopodobnie z tego też powodu, niestety dość często, dochodzi do sytuacji, kiedy po ujawnieniu zwłok lub szczątków ludzkich są one eksplorowane szpadlami przez funkcjonariuszy policji, którzy koncentrują się przede wszystkim na ich wykopaniu, przeniesieniu do worka transportowego i przewiezieniu do najbliższego zakładu medycyny sądowej. Autorom znane są również sytuacje, kiedy działania tego typu realizowane były przy użyciu koparki. Oczywiście wobec tak inwazyjnych i nieprofesjonalnych działań może dojść do uszkodzenia lub całkowitego zniszczenia materiału dowodowego, w tym również do bezpośredniego uszkodzenia zwłok lub szczątków ludzkich, odzieży, rzeczy osobistych znajdujących się przy ofierze itp. W takiej sytuacji rozróżnienie obrażeń post mortem i ante mortem może okazać się utrudnione lub niemożliwe. Przede wszystkim jednak źle przeprowadzone oględziny zwłok w miejscu ich odkrycia nie pozwolą na uchwycenie całego kontekstu związanego np. z głębokością jamy grobowej, tego, jak zwłoki zostały w niej ułożone, oraz tego, czy pod zwłokami lub w ich bezpośredniej okolicy po ich pogrzebaniu nie pojawiły się dodatkowe ślady, które mogą zostać wykorzystane tak w procesie wykrywczym, jak dowodowym. Innymi słowy — od jakości tych oględzin zależeć będzie przebieg prowadzonego postępowania ${ }^{12}$.

Mając na uwadze powyższe spostrzeżenia, zasadne wydaje się zaproponowanie sposobu działania w takich sytuacjach. W toku prowadzonych działań należy dążyć do jak najlepszego udokumentowania stanu faktycznego przy jednoczesnym pełnym rozpoznaniu całego miejsca, w którym zwłoki zostały ujawnione. Zważywszy na fakt, iż mówimy

12 Por. K. Juszka, Analiza wpływu oględzin kryminalistycznych na wykrywalność sprawców zabójstw, Kraków 2013. 
o zwłokach, które zostały pogrzebane w ziemi, najwłaściwsze wydają się być metody archeologiczne. Doświadczeni w „czytaniu z ziemi” archeolodzy, często wobec braku innych źródeł informacji, muszą umieć odnaleźć, zabezpieczyć i właściwie zinterpretować odkrywane w toku prac wykopaliskowych źródła materialne. Czynnościom tym obligatoryjnie towarzyszy sporządzanie dokumentacji opisowej, rysunkowej i fotograficznej ${ }^{13}$.

W celu wykazania zasadności powyższego autorzy przywołują w tekście konkretną sprawę, w której jeden z nich wystąpił w charakterze biegłego ${ }^{14}$. Jednocześnie autorzy pragną zaznaczyć, iż prokurator referent sprawy wyraził zgodę na użycie w celach naukowych prezentowanych zdjęć z oględzin, w których M. Wepsięć jako biegły z zakresu medycyny sądowej brał udział, z zastrzeżeniem, że udostępniony materiał może być użyty w taki sposób, aby uniemożliwił identyfikację osób, okoliczności oraz miejsca ujawnienia zwłok. Powyższe zastrzeżenia indukują konieczność bardzo zdawkowego i ogólnego zaprezentowania przebiegu przedmiotowych czynności procesowych, jedynie ze zwróceniem uwagi na zasadnicze ustalenia, do których doszło dzięki zastosowanej metodzie oględzin, w szczególności współpracy z archeologami oraz biegłym z zakresu medycyny sądowej.

\section{Krótki opis przypadku}

Podczas poszukiwań starej studni właściciel posesji na niewielkiej głębokości, sięgając ręką pod nieregularny fragment betonu przykrywający gruz, chwycił, jak mu się zdawało, kawałek gałęzi. Okazał się on kością udową (fot. 2), wraz z którą ze znacznej głębokości właściciel posesji wyciągnął za panewkę kość biodrową.

Na miejscu, pomimo wcześniejszych przygotowań do sprowadzenia koparki i szpadli dla funkcjonariuszy policji, prokurator po konsultacji z biegłym z zakresu medyny sądowej wydał postanowienie o powoła-

13 Coraz częściej sięga się po nowe technologie, przede wszystkim po skaner 3D.

14 Sprawa o sygn. akt PR1 Ds.547.2018 prowadzona przez prokuraturę rejonową w Środzie Śląskiej w sprawie o czyn z art. 148 § 1 k.k. W sprawie tej organ procesowy powołał jako biegłego z zakresu medycyny sądowej dra M. Wepsięcia. 


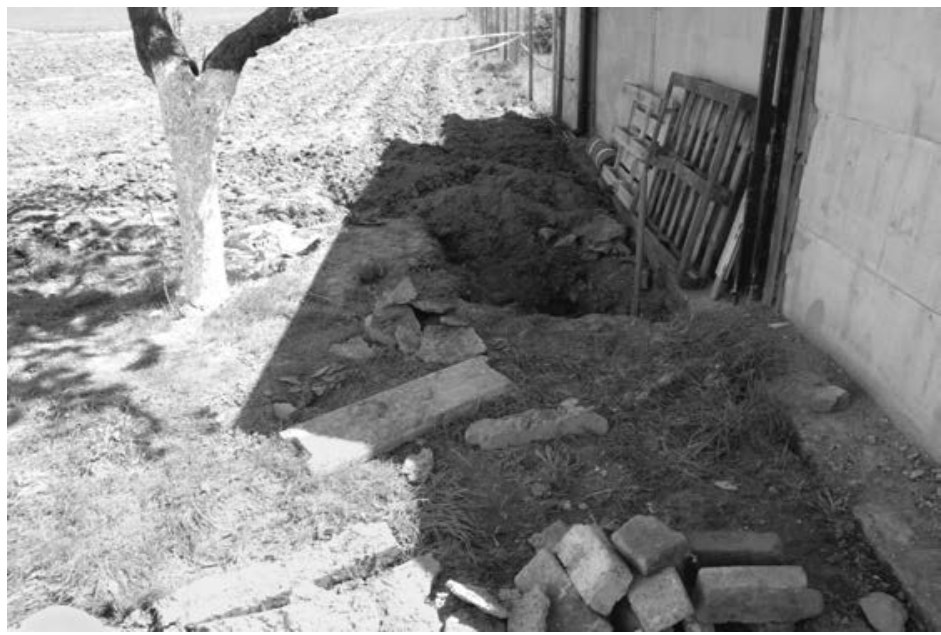

Fot. 1. Widok ogólny miejsca ujawnienia szczątków po częściowym usunięciu gruzu (dokumentacja fotograficzna pochodzi z akt sprawy)

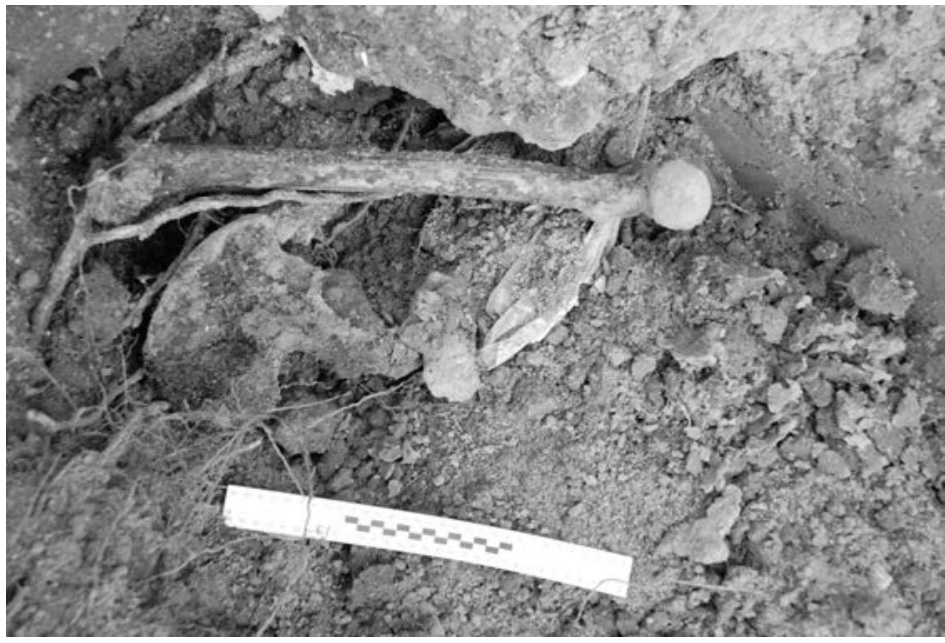

Fot. 2. Ujawnione przez właściciela posesji części szkieletu ofiary (dokumentacja fotograficzna pochodzi z akt sprawy) 
niu biegłych z zakresu archeologii. Przeprowadzone prace ziemne miały charakter badań archeologicznych, a ich zadaniem było odsłanianie kolejnych nawarstwień oraz interpretowanie sekwencji stratygraficznych, które pozwoliły w efekcie na zrekonstruowanie przebiegu pochówku. Podstawowym zadaniem na tym etapie było uchwycenie pierwotnego zarysu wkopu, w którym zdeponowane zostały ludzkie szczątki, a w późniejszym etapie interpretacja sposobu ich ułożenia w jamie grobowej. Początkowo widoczne ułożenie wzajemne kości sugerowało możliwość nieanatomicznego ułożenia kości względem siebie, co mogłoby wskazywać np. na ich wcześniejsze rozczłonkowanie.

Podczas stopniowego ujawniania szczątków metodami archeologicznymi działano w obrębie pierwotnie wykopanego przez sprawcę dołu (fot. 3), co pozwoliło stwierdzić, że sprawca, kopiąc dół, musiał wyciąć korzenie pobliskiego drzewa, które przebiegały przez kopany dół i które już w sposób znaczący zdążyły odrosnąć (fot. 4, 5, 6).

W końcowej fazie oględzin odsłonięto czaszkę, w zakresie której ujawniono złamania (fot. 7,8).

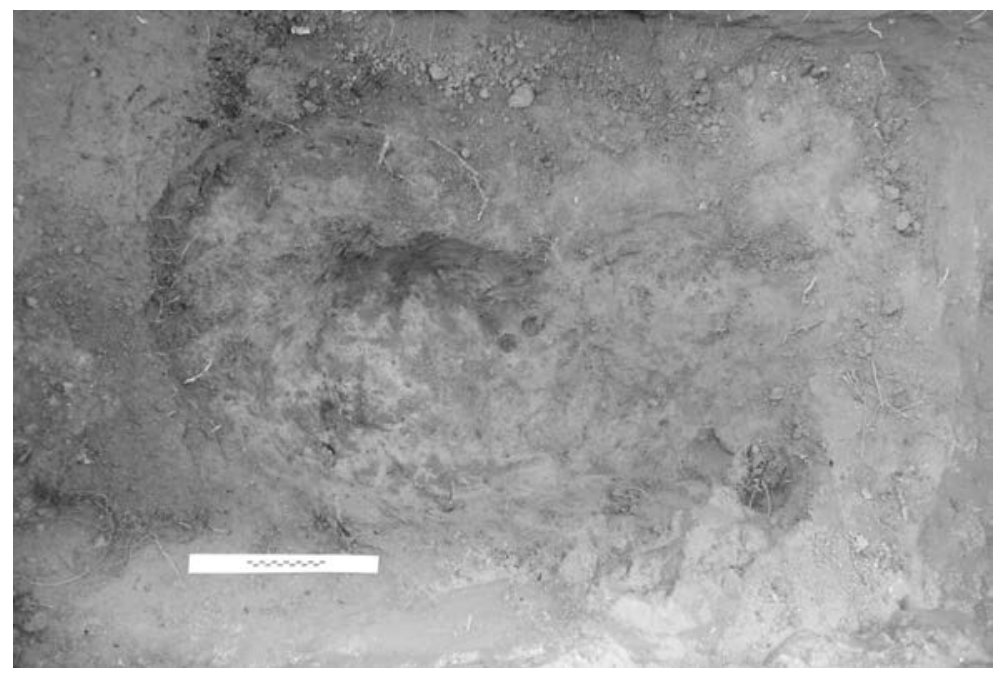

Fot. 3. Widok pierwotnego zarysu dołu, w którym została zakopana ofiara, już po wydobyciu szczątków ofiary oraz zabezpieczeniu odrastających korzeni (dokumentacja fotograficzna pochodzi z akt sprawy) 


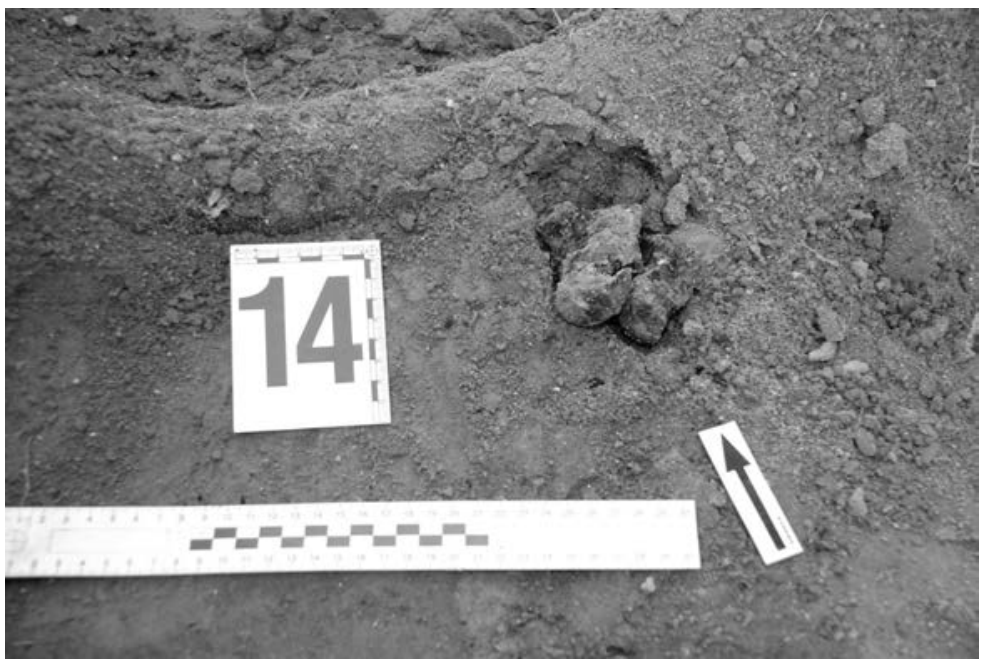

Fot. 4. Ujawnione kości stopy ofiary znajdujące się przy miejscu odcięcia korzenia (dokumentacja fotograficzna pochodzi z akt sprawy)

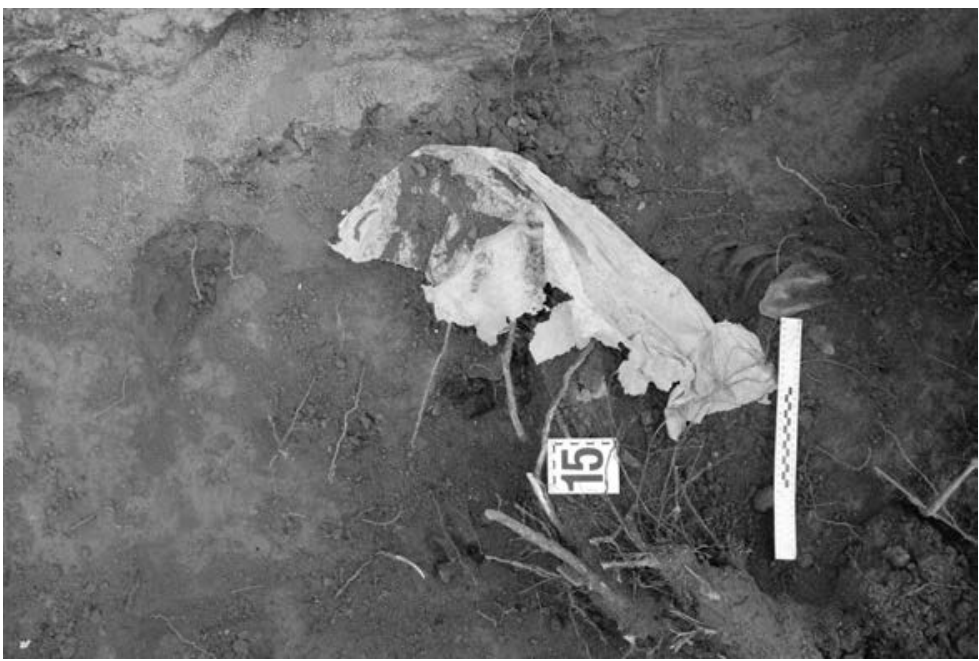

Fot. 5. Widoczne odrosty korzenia w miejscu jego wcześniejszego odcięcia przerastające szczątki (dokumentacja fotograficzna pochodzi z akt sprawy) 


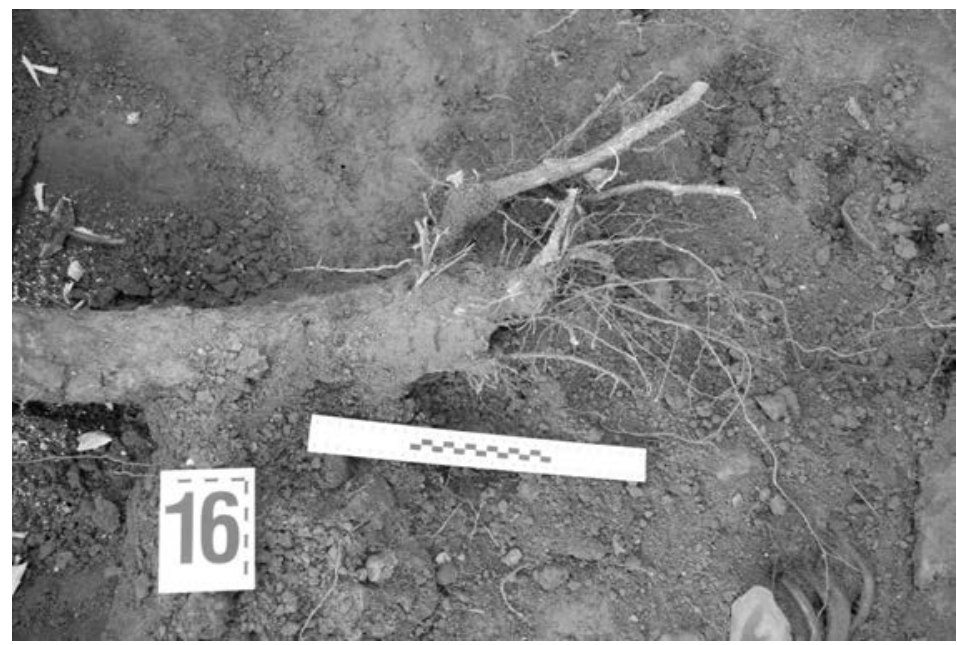

Fot. 6. Widoczne odrosty korzenia w miejscu jego wcześniejszego odcięcia zbliżenie na miejsce odcięcia (dokumentacja fotograficzna pochodzi z akt sprawy)

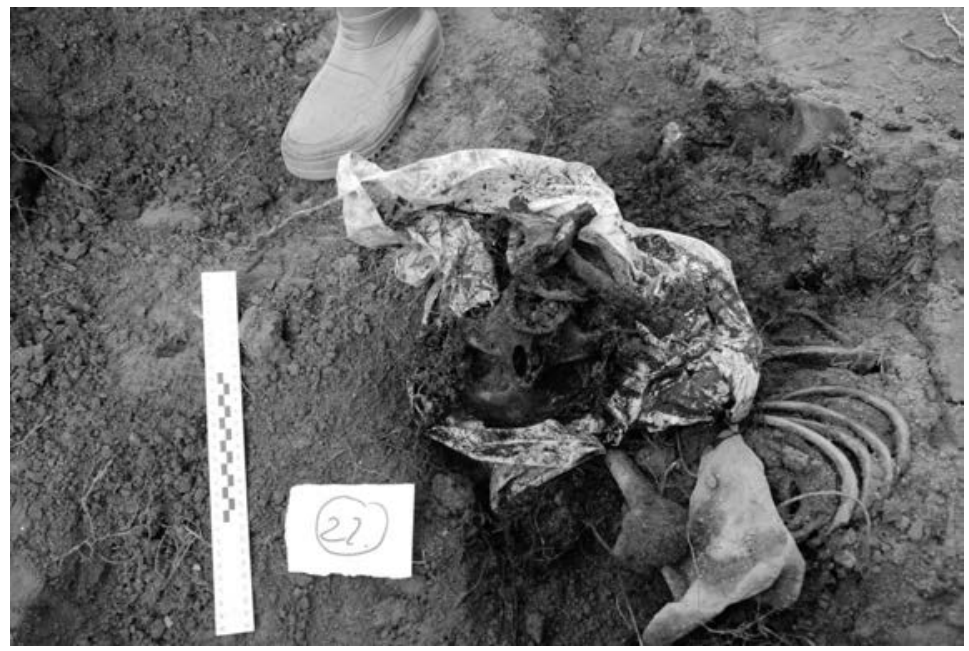

Fot. 7. Odsłonięta czaszka ofiary przed jej wydobyciem (dokumentacja fotograficzna pochodzi z akt sprawy) 


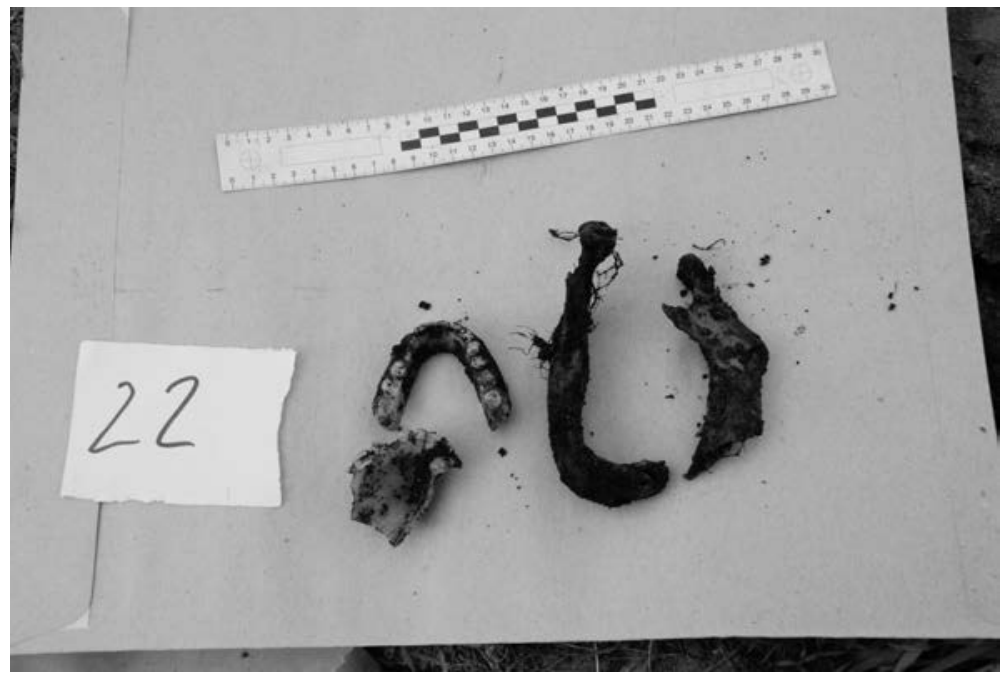

Fot. 8. Ujawnione złamanie żuchwy oraz złamania protez zębowych (dokumentacja fotograficzna pochodzi z akt sprawy)

W przedmiotowym przypadku wykorzystanie technik archeologicznych pozwoliło m.in. na ujawnienie faktu ścięcia przez osobę zakopującą zwłoki — prawdopodobnie sprawcę, mocno już odrośniętych korzeni pobliskiego drzewa, co mogłoby zostać pominięte w sytuacji, kiedy działania te realizowane byłyby bez udziału archeologów.

Roślinność ujawniana w ziemi nad zwłokami może okazać się przydatna do ustalenia czasu zakopania zwłok, jednak zazwyczaj takie ustalenia pozwalają na wyciągnięcie wniosków, że zakopanie zwłok nastąpiło nie wcześniej niż kilka miesięcy lub kilka lat od daty ich ujawnienia. W przedmiotowej sprawie zaistniała możliwość bardzo dokładnej oceny wieku odrośniętego korzenia, co bardzo zawęziło określenie czasu zakopania zwłok.

Stopniowe odsłanianie szczątków pozwoliło ustalić, że kości znajdują się w porządku anatomicznym, tj. zwłoki zostały zakopane w całości, a początkowe ułożenie odsłanianych kości mogło sugerować ułożenie nieanatomiczne kości, wskazując np. na rozczłonkowanie zwłok przed ich zakopaniem. Fakt taki może mieć decydujące znaczenie dla dalszych roz- 


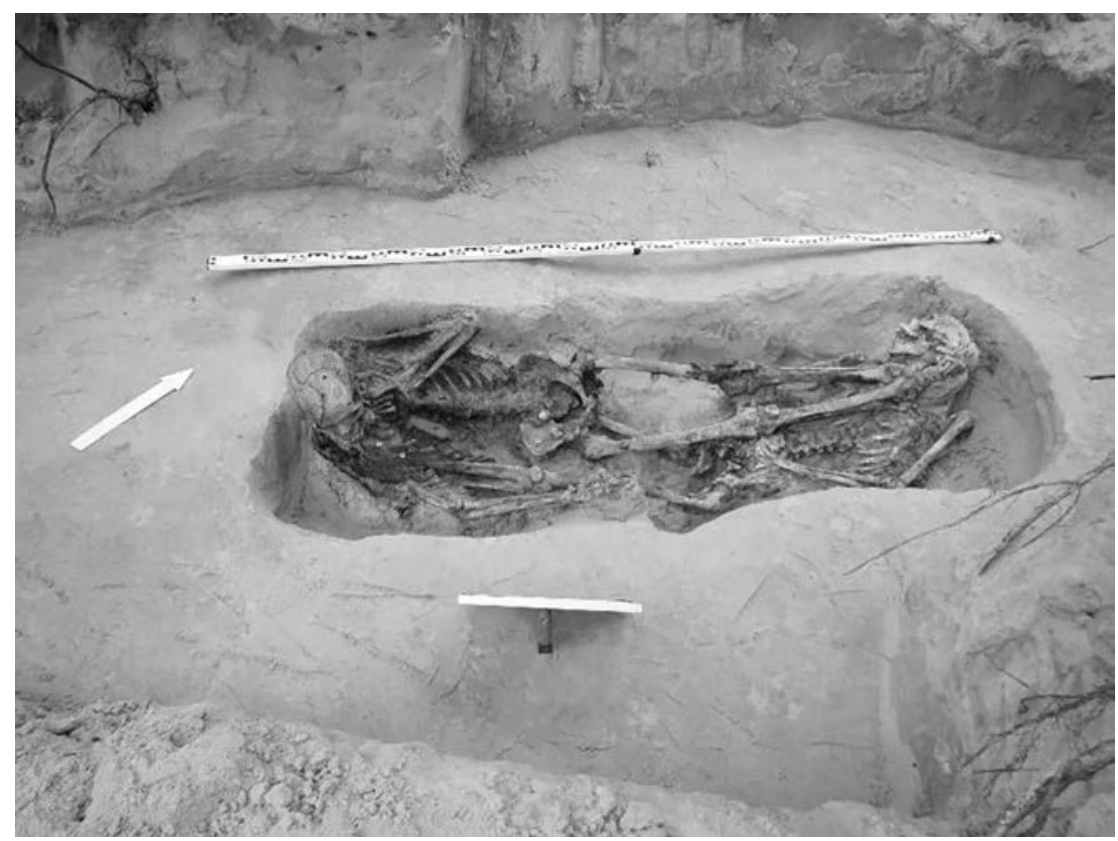

Fot. 9. Modelowy przykład prawidłowo wyeksplorowanego i przygotowanego do podejmowania szczątków miejsca pochówku. W jamie grobowej widoczne szczątki dwóch zastrzelonych ofiar w układzie anatomicznym (fot. T. Borkowski)

strzygnięć w analogicznych sprawach ${ }^{15}$. Potwierdza to inny przykład oględzin zwłok, w których uczestniczył M. Wepsięć. Zabezpieczono wówczas oddzieloną całkowicie zeszkieletowaną głowę znajdującą się w pobliżu tułowia, co sugerowało jej przestępcze oddzielenie. Ze względu na znaczne zeszkieletowanie szczątków, brak typowych dla oddzielania głowy od tułowia uszkodzeń czaszki i kręgosłupa szyjnego oraz miejsce ich ujawnienia (otwarta przestrzeń), nie można było wykluczyć jej pośmiertnego oddzielenia, np. przez żerujące zwierzęta. W zakresie czaszki złamany był jedynie jeden z wyrostków rylcowatych. W trakcie czynności do spowodowania śmierci przyznała się jedna z zatrzymanych osób, podając, że głowę odcięła uderzeniami krawędzi szpadla od góry, gdy ofiara leżała żywa na

15 Jeśli w toku oględzin okazałoby się, iż sprawca przed zakopaniem zwłok rozkawałkował je, musiałby się liczyć z dodatkowym zarzutem z art. $262 \S 1$ k.k. (znieważenie zwłok). 
ziemi. Choć zdawałoby się, że użycie mało precyzyjnego narzędzia musiałoby spowodować rozległe uszkodzenia czaszki i kręgosłupa szyjnego, to na szkielecie widoczne było jedynie złamanie wyrostka rylcowatego (co jako jedyne podczas oględzin zasugerowało autorowi możliwość odcięcia głowy). Podczas sekcji zwłok (wykonanej przez innego specjalistę medycyny sądowej) nie wykazano innych uszkodzeń kości kręgosłupa szyjnego i czaszki. W takiej sytuacji pochowanie zwłok w pozycji jedynie zbliżonej do anatomicznej podczas wydobywania ich szczątków w sposób zazwyczaj stosowany wręcz uniemożliwiłoby ustalenie faktu odcięcia głowy. Dodatkowo podkreślić należy, że często nie ma możliwości odróżnienia, czy stwierdzone złamania kości miały związek ze śmiercią ofiary, czy też wynikły z nieostrożnego wydobywania jej szczątków, co ze względów oczywistych może mieć wpływ na wnioski co do przyczyny śmierci i jej okoliczności.

Zdaniem autorów uchwycenie pierwotnego zarysu wkopu, w którym ujawnione zostały zwłoki lub szczątki ludzkie, pozwala na zrekonstruowanie całego kontekstu zdarzenia, tj. ustalenie powiązania odkrytych szczątków z ujawnionymi we wkopie przedmiotami osobistymi ofiary lub np. rzeczami zgubionymi bądź celowo wrzuconymi do grobu przez sprawcę. Analiza taka pozwala na określenie, czy pochówek taki można uznać za jednoczasowy, czy też np. wtórnie wkopano się w taki grób, zakłócając jego oryginalny charakter. Informacje pozyskane w toku prawidłowo przeprowadzonych oględzin, z jednej strony, mogą dostarczyć cennych informacji o modus operandi sprawcy, z drugiej zaś mogą przyczynić się do skutecznej identyfikacji tożsamości odkrytej ofiary.

\section{Podsumowanie}

W opinii autorów wydobywanie zakopanych zwłok lub szczątków ludzkich w przypadku podejrzenia przestępnego spowodowania śmierci obligatoryjnie powinno odbywać się z udziałem archeologów i specjalisty medycyny sądowej, gdyż taki sposób działania zwiększa możliwość ujawnienia istotnych dla sprawy dowodów, umożliwia ocenę anatomicznego ułożenia kości względem siebie, zabezpieczenie zwłok lub szczątków przed ich wtórnym uszkodzeniem oraz ogranicza możliwość 
przypisania do danego zdarzenia przedmiotów znajdujących się w ziemi w pobliżu, ale ze sprawą niezwiązanych.

Interdyscyplinarny charakter współczesnej kryminalistyki wskazuje na praktyczne możliwości wykorzystywania w toku prowadzonych oględzin ekspertów różnych dziedzin. Coraz częściej w działaniach takich uczestniczą archeolodzy sądowi ${ }^{16}$. Wydaje się, iż w toku procedury szkoleniowej funkcjonariuszy policji powinien znaleźć się blok informacji poświęcony wykorzystywaniu technik archeologicznych zarówno podczas poszukiwań miejsca, w którym sprawca ukrył zwłoki, jak i podczas samego procesu ich ekshumowania. Działania takie prowadzone są już od lat przez policję holenderską, duńską, francuską i niemiecką. W kwietniu 2020 roku praktyczne warsztaty z tej dziedziny (Forensic Search and Recovery Clandestine Graves) przeprowadzone zostaną w Polsce ${ }^{17}$.

\section{Bibliografia}

Archeologia sadowa w teorii i praktyce, red. M. Trzciński, Warszawa 2013.

Barone P.M., Groen W.J.M., Multidisciplinary Approaches to Forensic Archaeology, Springer 2018.

Całkiewicz M., Oględziny zwłok i miejsca ich znalezienia, Warszawa 2010.

Gawliński A., Jak pozbyć się zwłok. Specyfika działania sprawców zabójstw i ich postępowanie ze zwłokami, Olsztynek 2018.

Grzywno-Dąbrowski W., Badanie zwtok i miejsca, gdzie byty znalezione, Warszawa 1959.

Juszka K., Analiza wpływu oględzin kryminalistycznych na wykrywalność sprawców zabójstw, Kraków 2013.

Surwiło A., Oględziny zwłok i miejsca ich znalezienia jako kompleksowa czynność postępowania przygotowawczego, Warszawa 2019 (maszynopis rozprawy doktorskiej w archiwum Wydziału Prawa i Administracji Uniwersytetu Warszawskiego).

16 P.M. Barone, W.J.M. Groen, Multidisciplinary Approaches to Forensic Archaeology, Springer 2018; Archeologia sadowa w teorii i praktyce, red. M. Trzciński Warszawa 2013.

17 Zob. http://enfsi.eu/agenda/forensic-search-and-recovery-clandestine-graves/ (dostęp: 2.03.2020). 


\section{Akty prawne}

Metodyka oględzin miejsc przestęstw o charakterze terrorystycznym $i$ katastrof oraz identyfikacji ciat ofiar, załącznik do pisma nr Aom-1369/2012 Zastępcy Komendanta Głównego Policji z dnia 24 października 2012 roku.

Procedury postępowania Policji podczas organizowania i przeprowadzania oględzin miejsca przestępstwa, Warszawa 2001, załącznik do pisma Komendanta Głównego Policji nr Ad-1078/2001 z dnia 7 sierpnia 2001 roku.

Ustawa z dnia 6 kwietnia 1990 roku o Policji, Dz.U. 1990 Nr 30, poz. 179, z późn. zm.

Ustawa z dnia 6 czerwca 1997 roku Kodeks postępowania karnego, Dz.U. 2020 poz. 30. Wytyczne nr 3 Komendanta Głównego Policji z dnia 30 sierpnia 2017 roku w sprawie wykonywania niektórych czynności dochodzeniowo-śledczych przez policjantów, Dz. Urz. 2017.59.

\section{Źródła internetowe}

Strona internetowa European Network of Forensic Sciences Institute: http://enfsi.eu/documents/ best-practice-manuals/ (dostęp: 2.03.2020) oraz http://enfsi.eu/agenda/forensic-search-and-recovery-clandestine-graves/ (dostęp: 2.03.2020).

Strona internetowa policji: http://clkp.policja.pl/clk/aktualnosci/175202,Pierwsze-posiedzeniepolskiego-Zespolu-DVI.html (dostęp: 2.03.2020).

\section{Inspection of buried corpse and examination of the place of revealing the corpses in the event of suspected criminal cause of death - a proposal to organize procedural activities. Case study}

Summary

Inspections of corpses or human remains that have been buried should be carried out in close cooperation with police officers, a forensic doctor and archaeologists appointed as experts. Archaeological methods are able to accurately reconstruct the course of the burial itself and capture valuable evidence that can help in the reconstruction of the perpetrator's modus operandi and help to determine the identity of the victim.

Keywords: best practice, examination of corpses, exhumation, forensic archeology. 